\title{
How Traditional Knowledge Comes to Matter in Atlantic Salmon Governance in Norway and Finland
}

\author{
Camilla Brattland ${ }^{1}$ and Tero Mustonen ${ }^{2}$
}

(Received 28 August 2017; accepted in revised form 8 June 2018)

\begin{abstract}
The article compares different models for knowledge production, all of which include traditional knowledge, as part of Norwegian and Finnish Atlantic salmon (Salmo salar) research and management projects. Our hope is to contribute constructively to more socially robust knowledge production in Arctic environmental governance. Through investigating how traditional knowledge comes to matter at local, regional (national), and international levels in different Atlantic salmon research and governance projects in Norway and Finland, we examine the social robustness of different approaches to knowledge co-production. In general, the projects that seem to fulfill Arctic expectations of traditional knowledge co-production with science (projects with high legitimacy) seem to have the least impact on policy, and vice versa. We argue that expectations at the international policy level towards traditional knowledge integration with science are at times unrealistically high and hard to meet at local levels and in national policy contexts. We therefore argue for rethinking how a legitimate and policyrelevant knowledge co-production process should be conducted. Arctic policy levels, Norwegian and Finnish environmental authorities, and salmon conservation science could fruitfully draw lessons from the Näätämö co-management project, which is already referred to as an example of best practice in Arctic environmental governance. To achieve social robustness, projects need to balance scientific credibility with legitimacy among local and Indigenous rights holders. This balance might entail giving up on expectations of integrating traditional ecological knowledge with science and embracing the undefined spaces within Arctic and Indigenous knowledge production.
\end{abstract}

Key words: Atlantic salmon; governance; Finland; Norway; Sámi; knowledge co-production; traditional knowledge; Näätämö River; Barents Sea; Indigenous rights

RÉSUMÉ. Cet article compare différents modèles de production de connaissances émanant de projets norvégiens et finlandais de recherche et de gestion du saumon atlantique (Salmo salar). Tous les modèles incluent les connaissances traditionnelles. Nous espérons jouer un rôle constructif dans la production plus robuste de connaissances du point de vue social en matière de gouvernance environnementale dans l'Arctique. Nous avons fait des recherches pour déterminer l'importance des connaissances traditionnelles sur les scènes locale, régionale (nationale) et internationale dans le cadre de divers projets de gouvernance et de recherche sur le saumon atlantique en Norvège et en Finlande, après quoi nous nous sommes penchés sur la robustesse des différentes approches de coproduction de connaissances du point de vue social. En général, les projets qui semblent satisfaire aux attentes de l'Arctique en matière de coproduction de connaissances traditionnelles avec la science (les projets fortement légitimes) sont ceux qui semblent avoir le moins d'influence sur les politiques, et vice versa. Nous avançons que les attentes du point de vue des politiques internationales en matière d'intégration des connaissances traditionnelles aux connaissances scientifiques sont, parfois, très irréalistes et difficiles à atteindre à l'échelle locale de même que dans le contexte des politiques nationales. Par conséquent, nous soutenons qu'il y a lieu de réexaminer comment un processus de coproduction de connaissances légitime et adapté aux politiques pourrait se faire. Les organismes d'établissement des politiques dans l'Arctique, les autorités environnementales de la Norvège et de la Finlande de même que la science derrière la conservation du saumon pourraient tirer de bonnes leçons du projet de cogestion Näätämö, déjà considéré comme un exemple de pratique exemplaire en matière de gouvernance environnementale dans l'Arctique. Afin d'atteindre la robustesse sociale, les projets doivent équilibrer la crédibilité scientifique et la légitimité chez les détenteurs de droits ancestraux et locaux. Cet équilibre pourrait signifier la nécessité d'abandonner les attentes en matière d'intégration des connaissances écologiques traditionnelles aux connaissances scientifiques, et d'accepter les espaces indéfinis au sein de la production de connaissances propres à l'Arctique et aux indigènes.

Mots clés : saumon atlantique (Salmo salar); gouvernance; Finlande; Norvège; Sámi; coproduction de connaissances; connaissances traditionnelles; rivière Näätämö; mer de Barents; droits ancestraux

Traduit pour la revue Arctic par Nicole Giguère.

${ }^{1}$ Corresponding author: UiT - The Arctic University of Norway, UiT Norges arktiske universitet, PB 6050 Langnes, 9037 Tromsø, Norway; camilla.brattland@uit.no

${ }^{2}$ University of Eastern Finland and Snowchange Cooperative, Havukkavaarantie 29, FIN 81235 Lehtoi, Finland; tero@snowchange.org

(C) The Arctic Institute of North America 


\section{INTRODUCTION}

In the Indigenous Arctic context and beyond, the principle of including traditional ecological knowledge (TEK) in the knowledge basis for environmental management is gaining increasing recognition. Two of the most central international guidelines on TEK and Indigenous knowledge in the Arctic context, the Akwé: Kon guidelines developed under the auspices of the Convention on Biological Diversity (CBD Secretariat, 2018) and the Ottawa Traditional Knowledge Principles (Indigenous Peoples' Secretariat, 2014), emphasize the importance of TEK in knowledge production for sustainable management of the environment. However, when TEK plays a role in environmental management, it is not always obvious at national and local levels how to implement these guidelines in policy. Given the stated importance of TEK for environmental management, how does it matter at local, regional, and international levels in the Arctic, under what conditions does TEK actually have an impact on management and on policy, and how could socially robust knowledge production involving Sámi stakeholders be best achieved?

Several successful official co-management arrangements already exist in the Arctic. One example is in the Inuvialuit Home Settlement Area, Northwest Territories, Canada, where knowledge co-production with science and TEK is a central part of the arrangement (see e.g., Johnson et al., 2015). Another example, which is analyzed in more detail in this article, is the co-management arrangement for the river called Näätämo in Finnish (Neiden in Norwegian, and Njauddâm in Sámi), which includes the Skolt Sámi as active partners and knowledge producers (Arctic Council, 2013; Mustonen and Feodoroff, 2013; Mustonen and Mustonen 2016; Carson and Peterson, 2016). In other cases, however, resource management is heavily criticized for its ignorance of traditional knowledge in general or for having appropriated and misused knowledge that local and Indigenous peoples were contributing. An example is the case of the Tana River system (called Deatnu in Sámi, Teno in Finnish, Tana in Norwegian) on the Norwegian/Finnish border. Although local institutions participate actively in management, and the rights holders have gained a much larger say in the distribution of salmon fisheries in recent years, salmon biology is still criticized for its ignorance of TEK as a knowledge basis for the regulations enacted by the respective Norwegian and Finnish management authorities (Ween, 2012a, b; Joks, 2016; Joks and Law, 2016). Holmberg (2018) particularly points to fish biologists' tendency to consider Sámi knowledge as a source of data on specific factors related to salmon rather than a knowledge system, and that traditional salmon fishers and fish biologists might not even speak of the same salmon (Holmberg, 2018:47). The legitimacy with which knowledge production is carried out in practice, what different actors mean by including TEK in the knowledge basis for management, and its implementation in national and local management, can however differ greatly between projects, and between national and local contexts.
In this article we investigate different ways in which TEK comes to matter in Arctic environmental policy (both how it materializes and what impact it has on management). We aim to describe how and under which conditions TEK influences management outcomes and policy, using different examples of Sámi stakeholders' participation in processes of knowledge production for research and management of wild Atlantic salmon in Norway and Finland. After introducing some main principles articulated by national government and Indigenous policy actors on the subject, we compare relevant cases in which salmon fishers and their knowledge (including local ecological knowledge, and fishers' knowledge in addition to TEK) were included or not included as part of research, co-management initiatives, or both (Berkes, 2009, 2012; Mustonen and Feodoroff, 2013; Apgar et al., 2016) in the field of Atlantic salmon governance. We use criteria of policy-relevant knowledge production (Cash et al., 2002, 2003; Tengö et al., 2014) to assess and compare the role of TEK (its legitimacy, credibility, and salience) in these cases. Another important purpose of this paper is to review what has been achieved so far and to suggest how participatory research and knowledge production in this field could be organized in the future.

The article takes a bird's-eye view of relations between scientific knowledge and TEK in the field of Atlantic salmon governance in Norway and Finland, thus attempting to contribute to a broader discussion on traditional knowledge and its production in Arctic environmental governance. In Atlantic wild salmon governance, the Norwegian and Finnish environmental authorities are the two main decision makers, together with Russia, for the governance of Atlantic salmon from coastal regions to inland rivers from the Norwegian coast to Norwegian and Finnish salmon rivers. Because salmon migrate along rivers that cross international borders, national governance policies for the same river basin (e.g., the Deatnu/Tana and Näätämö/ Neiden Rivers) are not synchronized. These different polices affect the Sámi and other local people in Finland and Norway and relations not only between the various fishers' groups along the salmon migration route, but also between the Sámi people and the Fennoscandian governments and between scientific and local and Indigenous knowledge production (see Ween, 2012a, b and Joks and Law, 2016 for an overview). In Norway and Finland, inclusion of TEK in environmental governance is promoted in principle, as for example through the Norwegian Nature Management Act (2008) and the Parks and Wildlife section of the Finnish Forest Service (Metsähallitus) implementation of the Akwé: Kon guidelines (Metsähallitus, 2013). Local and traditional knowledge is also broadly promoted by decision makers as an important part of the scientific knowledge basis for salmon biology and management. Indigenous actors and critical scholars alike, however, tend to argue that there is a gap between the intentions of national legislative frameworks to promote TEK inclusion in biodiversity and environmental management and implementation of this policy in the field of salmon governance. More often 
than not, those in the community who hold and pass on traditional knowledge are in practice insufficiently represented in the governance of Atlantic salmon, as argued by Joks and Law (2016) in the case of the Tana River. The central objective for the following discussion is to analyze how and in what different ways TEK comes to matter (how it is concretely materialized and what it means) in Arctic environmental policies and in local salmon research and co-management processes.

\section{Traditional Knowledge Production in Arctic Environmental Policy}

Traditional ecological knowledge (TEK), as a concept referring to the specific aspect of traditional knowledge (TK) derived from use of and interaction with the environment, has increasingly taken on a power of its own, especially since its inclusion in $\S 8 \mathrm{j}$ of the Convention on Biological Diversity, through its performance in key arenas of power such as Arctic Council projects, international panels (e.g., the International Panel on Biodiversity and Ecosystem Services (IPBES)), (Díaz et al., 2015; Tunon, 2018) and in international codes of conduct such as the Akwé: Kon and Tkariwhaie:ri guidelines. Many definitions exist for TK, TEK, local ecological knowledge (LEK), and other forms of non-scientific knowledge, which have lately been supplemented with definitions of local and Indigenous knowledges (ILK), especially in the context of the IPBES (Díaz et al., 2015; Tengö et al., 2014), and other international processes mentioned above. Common to many definitions in scholarly literature and in policy contexts, which for the Arctic context are dominated by English-language, North American definitions, is that they take as a point of departure a focus on TEK as a system, or theoretical "body of knowledge" that is similar to scientific knowledge, but different in the sense that it is drawn from the experiences of people in interaction with the environment (cf. Agrawal, 1995; Berkes, 2008). A particular Sámi definition of traditional knowledge, or árbediehtu, emphasizes the way knowledge is produced through traditional practices or skills (árbemáhttu) (Guttorm, 2011) and maintained through continuous interaction with and use of the environment.

At the Arctic policy level, the framework of the Arctic Council facilitates joint initiatives in which TEK is central to the research approaches suggested, such as the Exchange of Local Knowledge in the Arctic and other communitybased monitoring projects (Arctic Council, 2013; Johnson et al., 2015; Carson and Peterson, 2016; AMAP, 2017). The relatively recent Ottawa Traditional Knowledge Principles (Arctic Council Indigenous Peoples' Secretariat, 2014) emphasize rules of conduct for knowledge production process and the need for scientists and knowledge holders to work together to co-produce knowledge. The focus on the process that produces knowledge and who participates in knowledge production is mirrored in the scholarly literature on the democratization of science and socially robust knowledge production. According to Nowotny et al.
(2001), in what is theorized as a new mode of knowledge production, knowledge needs to be not only scientifically robust, but also socially robust in order to be accepted in society. A key point for our context is that knowledge as a basis for policy increasingly needs to be produced in collaboration with key stakeholders, such as Indigenous peoples, if it is to avoid criticism.

For the present analysis of knowledge production in Arctic environmental policy, we draw on approaches in the sociology of science literature on policy-relevant and socially robust knowledge production (Nowotny et al., 2001; Cash et al., 2003; Gross, 2006), as well as on science and technology studies approaches to the study of how things matter or are enacted (Law, 2004). According to Cash et al. (2002), policy-relevant knowledge is theorized as the procedures or methods that should be in place in order for knowledge to have an effect on policy, that is, for knowledge to be perceived as credible, salient, and legitimate enough to have an influence on decision making. Cash et al. (2002, 2003) and Tengö et al. (2014) view three criteria-credibility (the scientific adequacy of the technical evidence and arguments), salience (the relevance of the assessment to the needs of the policy makers) and legitimacy ("the perception that the production of information and technology has been respectful of stakeholders' divergent values and beliefs, unbiased in its conduct, and fair in its treatment of opposing views and interests"; (Cash et al., 2003:8086) — as central to producing "actionable" or policy-relevant knowledge for decision making. These criteria are context-dependent and subject to trade-offs: for example, decision makers may judge the legitimacy of the information to be more important than its credibility. Tengö et al. (2014:588) argue that in processes where Indigenous and local knowledge is concerned, the science-policy community needs to "acknowledge, respect, and involve experts from diverse knowledge systems in assessments and other knowledge-related processes, as well as in developing the procedures for how to design such processes." In the Arctic context, Fenge and Funston (2009) also emphasize the role of traditional knowledge in Arctic policy as a means of participation, rather than as data.

Given this background of focusing on the procedures for knowledge production and the participation of Indigenous peoples in this production, we are particularly interested in the policy relevance and also the legitimacy of knowledge production processes that include the participation of Sámi stakeholders and their knowledge.

The Ottawa Traditional Knowledge principles are particular examples of expectations regarding TEK integration. These guidelines are developed by Indigenous peoples themselves, thus giving a sense of what Indigenous political actors expect of Arctic knowledge production processes and what legitimacy means (how it matters) at the Arctic policy level. The principles were developed during a series of workshops organized by the Indigenous Peoples' Secretariat (IPS). At these workshops, IPS facilitated discussions and debate among experts nominated by the 
six Indigenous peoples' organizations that are Permanent Participants (PPs) of the Arctic Council, who collectively developed a set of 13 fundamental principles on traditional knowledge for use in Arctic Council projects. The 13 principles contain both definitions of traditional knowledge in an Arctic context and principles related to its use. The definition in the Ottawa Traditional Knowledge Principles (Arctic Council Indigenous Peoples' Secretariat, 2014:1) reads as follows:

a systematic way of thinking and knowing that is elaborated and applied to phenomena across biological, physical, cultural and linguistic systems. Traditional Knowledge is owned by the holders of that knowledge, often collectively, and is uniquely expressed and transmitted through Indigenous languages... .

The 13 principles refer to TK both as an epistemologically different way of knowing the world that will contribute to holistic knowledge about the Arctic environment and as information or knowledge that can be complemented with scientific knowledge. It is also stated that "the application of both TK and science should occur as a creative co-production of knowledge" (principle 11). Summed up, the principles constitute both expectations of what TK (including TEK) is, and certain rules for how to produce and co-produce knowledge with TK in a way that is perceived as legitimate by Indigenous peoples' Arctic organizations. It constitutes TK as a body of knowledge that on the one hand should be integrated with science in every "agreedupon project," but that on the other hand should primarily be produced by Indigenous knowledge holders themselves.

Importantly for the role of TK in the Arctic Council is that the PPs are regarded as representatives of traditional knowledge holders in the Arctic. Any respectful integration of TK in Arctic Council projects thus needs to include either the PPs themselves directly, or someone that they regard as traditional knowledge holders (gaps in the geographical range of representation of PPs, however, remain on the community level). This emphasis on the procedural aspects of TK production is a result of the political process in which the principles were formed and must be read as such. The 2015 Ministerial meeting of the Arctic Council in Iqaluit did not adopt the principles themselves, but it approved certain recommendations for the integration of traditional and local knowledge, such as explaining how TK was integrated into a project, and if it wasn't, why not.

We see at least two implications of these expectations for TK research. On the knowledge production level, they materialize in standards and expectations for how TEK and Indigenous peoples should be included and treated in knowledge production processes (the legitimacy of the process). This is a much-needed standard in many contexts, especially in governance contexts where national legislation is not already in place that might safeguard the place of TK in environmental governance.
On the outcome level, however, experience has shown that such expectations are hard to fulfill and that the different enactments of traditional knowledge (by Indigenous politicians at the Arctic regional level, by salmon biologists, and by participants at the local community level) seem to be key in the current criticism of salmon biology and management. Across the Arctic, there are several examples similar to the case of the Tana River, in which TEK has been integrated, or attempts to integrate it have been made, as part of co-management projects or in the scientific knowledge base for resource management. However, these efforts have then been met with criticism from Indigenous quarters and from researchers, as also noted by Tengö et al. (2014).

The use of TEK in resource management among Indigenous groups in North America has, for instance, been characterized as a compartmentalization and distillation of knowledge. Nadasdy (2003), investigating the situation of the Kluane First Nation in Yukon, Canada, points to detrimental results from codifying and fixing governance, traditional land use, and knowledge into "European" or nation-state bureaucratic structures. In the case of the Kluane First Nation, the agreements and arrangements with the Canadian state produced significant financial and administrative resources for the community; however, as a result the traditional land uses and reproduction of knowledge significantly decreased because of "everybody working in the office" on TEK. Having traditional knowledge produced at so-called centers of calculation (Nadasdy, 1999:12), whether local or in collaboration with universities, is not necessarily perceived as legitimate by local stakeholders, nor does it necessarily make traditional knowledge research effective and meaningful beyond an exercise pursuant to international expectations. Eythórsson and Brattland (2012), who evaluated an attempt at interdisciplinary research involving Sámi and LEK of the marine environment in Norway, also found serious challenges with the integration approach to knowledge production. They argue that rather than attempting to produce local knowledge that can be compared to scientific data sets, forming partnerships with local knowledge producers should be a priority for science. In the case of Atlantic salmon research and management in Tana, Joks and Law (2016) and Ween (2012a) raise similar points, especially targeting the role of salmon conservation science in excluding TEK from the knowledge basis for decision making. We suspect that the criticism, both from Indigenous quarters and from social science scholarship, may have much to do with what we see as unrealistically high expectations of traditional knowledge integration with science and its politicization in Indigenous rights struggles.

Tengö et al. (2014) separate different knowledge production models, from integration to a parallel approach (in which TEK and science are not necessarily in dialogue with each other but part of the same knowledge base) to co-production (engaging in a mutual process at all stages of knowledge generation). In this latter process, mutual 
problem or goal formulation is critical to success. They suggest that part of the reason why TEK integration with science has been criticized has to do with the role of science in verification and validation of TEK. Referring to the critical points raised by Nadasdy (2006) and others, Tengö et al. (2014:582) argue that what can be termed the "integration and validation approach" to knowledge co-production has been criticized for many reasons. For example, criticism has been based on how appropriate the validation measures used are, to what extent relevant and locally legitimate knowledge is excluded and appropriated by researchers, and to what extent it may lead to disempowerment of local communities (Roué and Nakashima, 2002; Nadasdy, 2006; Tengö et al., 2014:582). Rather than attempting to validate knowledges, Tengö et al. (2014) argue for a multiple evidence-based approach that develops synergies across knowledge systems, and no knowledge system is given the role of external validator. However, this approach requires that all parties engage in a mutual process in which each knowledge system is given equal value.

In essence, we can say that even when Indigenous peoples participate in parts of the knowledge production process, but its application falls short of expectations, the process may still be seen as an appropriation of TEK, or as supporting colonial structures instead of empowering Indigenous governance systems. Expectation of a "success" while participating in international validation processes may also create expectations among Indigenous peoples. In theory then, legitimate knowledge production involving Indigenous and local knowledge seems to be defined by the degree to which Indigenous peoples participate in its production (cf. Fenge and Funston, 2009) and whether they accept its application.

\section{METHODS AND STUDY AREA}

This article focuses on three cases that involved local and Sámi salmon fishers in various stages of knowledge production and management, and which were met with both acceptance and criticism from Indigenous quarters. These cases were chosen because, to the best of our knowledge, they are the most important cases in recent years that have purposefully included TEK, local, and Sámi knowledge on Atlantic salmon (aside from the Deatnu/Tana River management) and because they illustrate different approaches to and practices of knowledge co-production that are important to highlight. The Deatnu/Tana case, which has already been thoroughly explored, especially by Joks (2016) and Holmberg (2018), presents a clear case of the privileging of scientific credibility over legitimacy, reflecting the local, Indigenous, and scholarly criticism of current state government management of the river. The complexity of the Deatnu/Tana river salmon management and how Sámi as rights holders and knowledge holders are included or not surely deserve more attention by decision makers and researchers alike. For the purposes of this article, however, in the context of politicization and critique of Fennoscandian salmon governance, we find it important to broaden the scope of inquiry to get beyond immediate political concerns and perhaps arrive at new insights from other cases, successful or not, in which TEK also plays a role in salmon management. Our case material includes the sea-based coastal fishery in Finnmark in Norway and the co-management of resources in the Näätämö basin in Finland in the east (see Fig. 1).

We use the literature and published results of the Näätämö River co-management project and Kolarctic salmon fisheries cases (since 2012) and review Indigenous knowledge holders' experiences with salmon management. For the Norwegian cases, that review is based on qualitative interviews with members of coastal salmon fishers' organizations and with individual fishers in Finnmark who harvest salmon from a diversity of salmon rivers as part of their mixed-stock fishery. The topics focused on environmental knowledge such as differences between salmon stocks (farmed and different wild stocks), migration patterns, and the fishers' views on how their participation and knowledge had influenced salmon management. The overarching method for our paper is applied comparative analysis of the varied situation in Norway and in Finland. Where appropriate, we complement this approach with policy analysis to identify key legislative and policy instruments. We also reflect on our own experience working inside these processes to assess success or failure and identify questions that need further investigation. An important motivation for choosing these cases is the authors' own engagement and ongoing involvement with local and Sámi struggles to participate in resource management in northern Norway and Finland. In the case of Näätämö, co-author Mustonen has been the coordinating scientist of the project since 2011 as director of the independent, non-profit Snowchange Cooperative (Mustonen, 2015). Assessment of success of these actions requires substantial distancing from the primary worksites. This has been achieved by critical self-reflection and presenting Näätämö results published in peer-reviewed journals. In the Norwegian cases, primary author Brattland has participated in a follow-up study to the Kolarctic Salmon project as a researcher, and in previous publications, such as Schreiber and Brattland (2012), followed the development of salmon fishing policies and impacts of aquaculture on wild salmon in Norwegian Sámi areas.

\section{SÁMI PARTICIPATION IN ATLANTIC SALMON FISHERIES IN ARCTIC NORWAY AND FINLAND}

Salmon is an important resource for Sámi and local populations settled on the coasts and along the large rivers in Fennoscandia. The salmon fishery in the Neiden/Näätämö River can be dated back to the 1740 s, when salmon fishery in the Varanger Fjord area in Finnmark is also mentioned in written sources. With dwindling salmon returns and 




FIG. 1. Finnmark County and Finland, including the location of the Tana and Neiden Rivers, and the Näätämö co-management area. Map courtesy of Johanna Roto.

increasing concern for the wild salmon in general around the North Atlantic, the sea-based drift net fishery was abandoned in 1989, and since the 1960s, the coastal and river fisheries have been cut back by shortening the allowable fishing period and limiting allowable fishing gear (Pedersen, 2010). During the last decades, the traditional fishery has gradually been reduced to little more than a recreational fishery, while the sports and recreational fishery has increased its volume and value, especially in Finland, which in 2017 had 1.6 million recreational fishermen and only about 2000 professional fishermen (ELY, 2018). The drastic cuts in the traditional fishery have led to numerous protests and criticism from local and Sámi fishers, from individual Sámi politicians and researchers, from communities, and from the Sámi Parliaments in Norway and Finland. The ongoing criticism has been most recently illustrated by the ongoing yearly occupation of an island in the Tana River by a group of Sámi activists called Ellos Deatnu, who declared a "moratorium" on salmon regulations in that part of the river in response to the 2016 agreement between Norway and 
Finland on salmon fisheries in the Tana (Holmberg, 2018). Criticism from the activists was partly related to the lack of inclusion of traditional knowledge and Sámi customary rights in the agreement, while the Sámi Parliaments of both countries pointed to the lack of proper consultation on the agreement prior to its ratification by the national parliaments (Yle, 2017).

In regard to rights to salmon fisheries, the Norwegian state does not recognize any specific Sámi right to fish or priority as a group in fishery regulations (Pedersen, 2010), such as those enjoyed by some First Nations in Canada (Harris, 2009). The Tana and Neiden Rivers (see Fig. 1), however, are governed by separate legal acts. The Tana Act (2014) extended the fishing right (limited to rod fishing only, new §5) to the general population in the Tana Valley, and upheld the previously acknowledged right to fish with any gear, including nets and weirs traditionally used by the Sámi, of inhabitants settled close to the river and annual producers of $2000 \mathrm{~kg}$ of hay ( $\$ 4)$. The Finnmark Act of 2005 contains a separate section (Chapter 4, \$28) on the Tana and Neiden Rivers, which states that the local population holds special rights to the watershed based on usage from time immemorial and local customs, and that the joint river management between Norway and Finland shall be conducted in consultation with the Sámi Parliament, affected municipalities, and holders of fishing rights in these waters.

The Skolt Sámi people in the Neiden/Näätämö area were granted specific rights to use resources in their area as a compensatory measure after their forced relocation by the Finnish state in the 1940s. Since then, the Skolt Sámi population has gone through a range of transformations. The "original" Skolt population was assimilated into Norwegian society, and the Kven minority in the same area adopted the cultural fishery in the river. The Skolt Sámi culture re-emerged in the basin after the 1940s when a group of Skolts from the Petsamo region was relocated there. The general political and cultural revitalization of Sámi cultures after the Second World War also contributed to this process. The special history and rights status of the Sámi is important context for interpreting current criticism of state regulations and salmon biology.

\section{The Norwegian Sea-based Salmon Fishery and its Management}

In Norwegian salmon research and management, local expertise is instrumental in salmon research and governance of salmon rivers (Rybråten and GomézBaggethun, 2016). Traditional knowledge is not systematically included as part of the knowledge basis in regular reports from the Scientific Council for Salmon Management (SCSM), but the Sámi Parliament and salmon fishers' organizations are represented in the government-led Cooperation Council for Anadromous Salmonids, which meets yearly for stakeholders to discuss salmon fishery regulations. Organizations of salmon fishers in Finnmark, as well as the Sámi Parliament in Norway, are engaged in defending the salmon fishery as a traditional way of life and an Indigenous right to fish (Sámi Parliament, 2017). The struggle concerns both riverine and sea-based fisheries, but we focus on the latter for the Norwegian case studies.

The sea-based salmon fishery has been an especially contested issue for a number of years. This mixed-stock fishery harvests both healthy and potentially vulnerable stocks, such as the Tana River stocks, because the river origin of the fish captured and the robustness of their original stocks are unknown. Norway upholds its seabased fishery since it is a right connected to private properties and because it has cultural and economic significance for the coastal Sámi (Lam and Borch, 2011). Since 2008, allowable fishing days in the coastal salmon fishery have been reduced considerably as a follow-up to the guidelines on mixed-stock fisheries of the North Atlantic Salmon Conservation Organization (NASCO) (Ministry of Climate and Environment, 200607; NASCO, 2009), to the point where, given weather constraints and their inability to fish continuously, salmon fishers in reality are left with few effective days between 1 June and the middle of July (Pedersen, 2010; Office of the Finnmark County Governor, 2018). This situation has been protested, especially by fishers in the traditional coastal Sámi homeland, who have attempted to take the case to court on the basis of their rights as Indigenous fishers. The Sámi Parliament has consulted with the authorities on the salmon fishing regulations and also included the coastal salmon fisher organizations in the consultations. The main argument of the Sámi, referring to traditional knowledge, has been that other factors, aside from the coastal mixedstock fishery, have led to low salmon returns and that salmon returns were not diminished in the past even though the harvest of the sea-based fishery was substantially higher (Sámi Parliament, 2017). The regulatory reductions of the sea-based salmon fishery were also brought to the attention of the UN Special Rapporteur on the rights of Indigenous peoples, who advised the Norwegian authorities to protect the sea-based salmon fishery by special measures according to Sámi traditions (UN Human Rights Council, 2016).

\section{Case 1: The Joint Norwegian-Sámi Salmon Working Group}

A special case of integrating traditional knowledge into the knowledge basis for management occurred between the Norwegian authorities and the Sámi Parliament as a result of the state's duty to consult with the Sámi in the aftermath of the 2008 reduction in the sea-based fishery. After the Sámi Parliament protested against the regulations on the grounds that they violated coastal Sámi fishing rights, the environmental authorities engaged the parliament in a dialogue. In 2011, the Sámi Parliament and the Directorate for Nature Management initiated a collaborative working group with the local coastal salmon fishers' organizations to produce a co-management framework for salmon management. The process (also described in Ween, 
2012b) lasted more than a year and resulted in a report that used both traditional and scientific knowledge as the basis for advice on salmon fishing regulations in northern Norway (Directorate for Nature Management and Sámi Parliament, 2011). Sámi historian and senior scholar Steinar Pedersen developed a list of items for the working group to investigate with regard to including traditional knowledge. Among these were the role of predators, such as seals, but also birds and fish that affect salmon survival in the context of the Tana River. Although salmon scientists had previously deemed the role of predators irrelevant to salmon management (see also Joks and Law, 2016), the joint working group acknowledged it as part of the input from traditional knowledge. Pedersen's report was based on historical sources and his own interviews with salmon fishers and was published together with the joint working group's report (Pedersen, 2011). The working group proposed a modest extension of the sea-based salmon fishery and initiation of a project for systematically including traditional knowledge in management.

The report and the procedural approach of the joint process, which included the views of both participating fishers and salmon scientists, were successful as an example of the beginning of co-production of knowledge for salmon management; however, the process stalled shortly thereafter. The reasons are unclear, but after the report was finalized, the Ministry of Environment decided against the proposed extended fishing times out of concern for the vulnerable Tana River salmon stocks, as well as Russian concerns about effects of the Norwegian fishery on salmon originating in Russian rivers. When the Ministry did not want to expand the fishing times, the consultations with the Sámi Parliament and the co-management process were discontinued. The abandonment of the co-management process led the Sámi Parliament and the Finnmark salmon fishers' organizations to renew their severe criticism of the environmental authorities in the following years. In 2016, they made a joint statement (Charter 2015 on seabased salmon fisheries) demanding that the allowable fishing times be reverted to the 2007 regulations, that the sea-based and river-based fisheries should bear equal burdens of the restrictions, and that local knowledge and customary management should be included in salmon management. This position is far from the rather modest claims arrived at in the joint working group, illustrating an increasing distance between these stakeholder groups and the environmental authorities. At the same time, sea-based salmon fishers are attacked by river-based salmon fishers' organizations for harvesting too many spawners, for not contributing to the overall well-being of salmon stocks, and for not creating the same economic value as sports and recreational fisheries (NRK, 2016). In general, then, even though the knowledge production process was perceived to be fair and just, including the Sámi as holders of traditional knowledge, the sudden abandonment of the process was disastrous for the relationship between the environmental authorities, salmon biologists, and Sámi stakeholders.

\section{Case 2: The Kolarctic Salmon Project}

Another process for integration of fishers' knowledge with science, if not particularly Sámi and Indigenous knowledge, was ongoing around the same time: namely the Kolarctic Salmon project (2011-13) (Kolarctic ENPI CBC project KO197) headed by the Finnmark County Governor and consisting of teams of Finnish and Norwegian salmon biologists. During the Kolarctic Salmon project, as many as 58 fishers from the entire northern Norwegian coast, including Sámi fishers, participated during the 2011 and 2012 fishing seasons by providing scale samples and information on salmon in their catches. The study, which covered the coastline of northern Norway, was made possible by collaboration between salmon biologists at the Norwegian Institute for Nature Research and local organizations of sea-based salmon fishers and scientific institutions. This collaboration was facilitated by the County Governor of Finnmark (the northernmost county in Norway). New genetic stock identification techniques made it possible - with high precision - to define the home region or river of each individual adult salmon captured at sea and thus to estimate the origin of the actual catches from the mixed-stock sea-based fishery (Ozerov et al., 2017). Fishers were tasked with registering data (such as size, weight, sex, and occurrence of farmed salmon), taking scale samples, and sending in whole fish to laboratories. The allowable fishing days were extended at both ends of the season for participating fishers, thus providing them with an extended research fishing period and monetary compensation for their work. Not only did scientists gain much more knowledge about what genetically distinct salmon stocks are targeted in the coastal fishery in the Barents region, but a baseline for knowledge on salmon catches was created through salmon fishers' participation in the project (Svenning et al., 2014).

The title page of the summary report on the Kolarctic Salmon project (Office of the Finnmark County Governor, 2013) states that it merged "modern science with traditional knowledge to improve the future management of Atlantic Salmon in the Barents region." Reports from the project refer to observations drawn from traditional knowledge, for instance that female salmon are the first to arrive, and that "traditional knowledge from the old salmon fishermen tells that there is some salmon migration early in the spring" (Niemelä et al., 2014:6). Qualitative interviews with participating salmon fishers in Finnmark (Porsanger, Tana, and Varanger Fjord) revealed that they hold a wealth of local environmental knowledge and observations of interactions between salmon and the marine environment, particularly on the performance of bend nets and bag nets in relation to changing wind and sea current conditions in the ocean. For example, fishers are sometimes not able to exploit the fishing season fully because of summer storms. Participation in the project had made these fishers more alert to the differences between farmed and wild fish, and they appreciated the longer fishing season provided by 
the project. In general, however, fishers did not feel that their participation had any impact on management or that their knowledge was taken into account. However, they were positive towards participating in research if it meant that they would be compensated for their participation and work effort as data collectors. None of the sea-based salmon fishers had high expectations about integration of their traditional knowledge with science, and most showed a curious and open attitude towards the new knowledge to come out of the Kolarctic salmon project.

The Kolarctic project results were directly relevant for policy, and all of the project's scientific reports were published on the web pages of the Finnmark County Governor (Office of the Finnmark County Governor, 2013). In general, it showed a much more nuanced picture of the mixed-stock fishery, making it possible to identify harvest pressure on river-specific stocks within the coastal fishery (Svenning et al., 2014; Ozerov et al., 2017). The most controversial knowledge was the new data on the extent to which sea-based fishers harvest salmon originating from Russian rivers. In particular, the sea-based fishery in the Varanger Fjord harvests more salmon belonging to Russian rivers than fishers in other regions, as in some catches the proportion of Russian salmon was as high as $54 \%$ in the inner part of the Varanger Fjord (Svenning et al., 2014). Although most Russian salmon rivers are within sustainable spawning target limits, the Varanger Fjord coastal salmon fishery was nonetheless reduced in the 2016 fishery regulations. Because of this, the fishers in the eastern part of Varanger Fjord (Southern Varanger salmon fishers' organization) claim that the authorities have applied the Kolarctic project results incorrectly. There was also pressure on NASCO from Russia and NGOs such as the Atlantic Salmon Fund to reduce the mixed-stock coastal fishery further (see also Mustonen and Feodoroff, 2013). At the NASCO meeting in 2014, the Sámi Parliament of Norway, represented for the first time, attempted to influence the member countries' (and especially Russia's) position on reductions in the mixed-stock fishery. The Sámi Parliament representative spoke in support of integrating an Indigenous perspective into the NASCO guidelines, pointing out that salmon fishing is a cornerstone of Sámi culture and that "management calls for a combination of biological knowledge and traditional knowledge" (NASCO, 2014:45). Norway and Russia did consider a reduction of the catches in the sea fishery for salmon in the Varanger Fjord area of salmon originating in Russian rivers (NASCO, 2015), which was implemented from the 2016 season.

The knowledge production model of the Kolarctic salmon project can be characterized as an "integration and validation" approach, in which fishers were used as information collectors and their information was integrated into the scientific knowledge base. Even though attempts were made to integrate traditional knowledge, the result was not substantial or relevant enough to have an impact on the outcomes and resulting management implications. The knowledge production process of the project is far from the international and Arctic expectations towards traditional knowledge production, but seems not to have attracted as much criticism from Sámi stakeholders as the Tana process or the demise of the joint working group.

\section{Case 3: The Näätämö Project}

This case explores the questions of Atlantic salmon governance and traditional knowledge in Finland in the Skolt Sámi home region located in the Näätämö/Neiden River catchment area, which empties into the Neiden Fjord, an arm of the Varanger Fjord in Norway (Niemelä et al., 2001; Mustonen and Feodoroff, 2013). The river remains one of the most relevant salmon spawning systems in the Fennoscandian North, and for Finland, it is the second most productive after Deatnu/Teno.

Official salmon governance of the Näätämö River rests internationally with the Finnish-Norwegian River Commission and the associated international fisheries agreements and commissions. It decides the macro-level uses of the river and quotas for fisheries. Most of the headwater systems with their spawning areas are located in Finland. Domestically the Ministry of Agriculture and Forestry has the mandate to govern the issues and resources related to salmon. Regionally this responsibility is diverted in part to the provincial Center of Economy, Transport and the Environment (ELY-keskus), representing the state officials and Metsähallitus, the Parks and Wildlife section of the Finnish Forest Service, which "owns" most of the lands in the basin. Metsähallitus regulates locally all the fishing, hunting, research and other activities within the basin. The Municipality of Inari, local businesses, and others have stakeholder roles too. On the Norwegian side of the Näätämö basin, the Norwegian minority, the Kvens, and a tourist fishery play a role in both licensing and harvesting on the river (Mustonen and Feodoroff, 2013).

The Näätämö River region is also the homeland of the Skolt Sámi peoples, who were resettled to the communities of Näätämö, Sevettijärvi, and others in the late 1940s after forced evacuations from the Soviet Union at the close of World War 2. The Näätämö basin used to be a home siida or territory of the Näätämö Skolts, who assimilated for the most part towards the end of the 19th century. The arriving Suonikylä Skolts therefore re-occupied Skolt Sámi space, albeit that of another tribe that had disappeared almost 50 years prior (Mustonen and Mustonen, 2011).

The Näätämö area has been designated as an official Wilderness Area in the IUCN Finnish demarcations. It is also affected by the Skolt Sámi Act of Finland, which gives the Skolt Sámi (out of all the Sámi groups in Finland, which also include Inari Sámi and North Sámi) the only specific legal framework that guarantees land-use privileges and access to fishing, herding, and hunting resources. The Act is not a land ownership document.

From the internal viewpoint of the Skolt Sámi, there are several relevant, preserved governance bodies. The Skolts, out of all Sámi groups, have preserved the Indigenous 
governance body of siida sobbar, Skolt Village Council (Mustonen and Mustonen, 2011). This Council represents the two home regions of the Skolts, the Näätämö area and the Nellim area, in all official business. The Näätämö River issues have been under the mandate of the Sevettijärvi Council. Additionally the family- or clan-specific harvest areas, trails, and network of cabins have been established through the Näätämö basin since 1940s. In summary, the Skolts have three levels of Indigenous governance in relationship to the Atlantic salmon: first, the Skolt Sámi Village Council, which represents them in official negotiations; second, the clan and family networks; and lastly, the demarcation of use territories across the inland Näätämö basin based on the family uses (Mustonen and Feodoroff, 2013).

Between 2006 and 2011, communities of the Eastern Sámi (including the Skolts) in Finland and in Russia, together with the Sámi Council, embarked on a historical first: a large documentation of traditional land uses and occupancies from the eastern shores of Kola Peninsula all the way to Inari Lake. This work was released in 2011 as the Eastern Sámi Atlas (Mustonen and Mustonen, 2011).

A topic within the atlas work was devoted to the traditional knowledge of climate change. In 2011, following a community-led self-reflection, the Skolt Sámi embarked on a collaborative management project of the Näätämö basin in response to the impacts of climate change on the Atlantic salmon.

The Skolt Sámi collaborative management project has now been working for six years to respond to the consequences of climate change, such as extreme drought, which affects the capacity of the Atlantic salmon to reach different parts of the basin (Mustonen and Feodoroff, 2013; Apgar et al., 2016). The project was officially chosen in June 2015 to represent the Skolt Sámi on the issues of river governance. From the viewpoint of this Indigenousled governance and climate adaptation mechanism, the bottom-up model uses new points of departure in salmon management.

The core aspect of co-management rests on the Skolt Sámi Act, which guarantees the Skolts, unlike other Sámi groups, specific geographical territories, i.e., the Näätämö basin on the issues of fisheries (Mustonen and Feodoroff, 2013). There is a Skolt Sámi team, consisting of reindeer herders and fishermen, who are paid for their time in the basin on the project work. A second Sámi unit consists of the staff and personnel of the Saa'mi Nue'tt cultural organization, consisting mostly of female staff and project leaders, who are tasked with the mandate of the culturallinguistic, mapping and database work of the project. They steer the entire project together with the fishermen. The science team numbers six to eight, depending on the season and issue, including geographers, limnologists, ecologists, and fish biologists. The stakeholders had been working before with co-management arrangements in Northeast Siberia and the Inuvialuit area in Canada to develop small-scale co-management models that have flowed to the Näätämö set-up (Mustonen and Mustonen, 2016). Failures and criticism of co-management arrangements in these global forums were studied closely before the implementation of the steps in Sevettijärvi. In short many of the international co-management regimes are bigger in scale, covering multiple ecoregions, species, and jurisdictions. Closest cooperation has been achieved with the Inuvialuit co-management. These North American partners have shared their monitoring mechanisms and geo-spatial tools, especially those regarding whitefish populations of the Mackenzie River, which come closest to the Näätämö fisheries. The main difference at this stage of the Näätämö work in relationship to the global processes is that it is addressing mostly aquatic species and habitats in the context of climate change resilience. Terrestrial systems await future options.

The Skolt Sámi have two main concerns for the Näätämö basin: first, the spawning and habitat areas of the Atlantic salmon need to be guaranteed to provide increased resilience in the face of rapid climate change. This concern includes the renewed harvest of the northern pike and burbot, species that affect salmon survival. Second, the past damages caused by dredging, forestry, boat access and other infrastructure and natural resource developments between 1950 and 1980 need to be addressed with ecological restoration of habitats to decrease drivers such as erosion, nutrient and organic loading, and "lost" spawning areas (Mustonen and Feodoroff, 2013).

Plans of action and restoration have been accomplished by first assessing how things are. The information flow from the Skolt Sámi teams produces the traditional knowledge observations of the basin, including weather and star lore events. This information is then compared with that of the science team to point to sites and drivers of change and their implications for salmon in the context of climate change. The project received international attention in 2014-17 as the Skolt Sámi, equipped with digital cameras, were the first to report the arrival of a southern beetle species (Potosia cuprea) in the basin. The TEK observation was then published in peer-reviewed science journals, leading to the establishment of visual-optic communal histories as a method to detect change in a subarctic basin (Mustonen, 2015). Similar observations have included sites of algae growth, new plant species, spawning locations, and sites of ecological damages. Results of the Näätämö project are published both as work reports, posters, online postings and in peer-reviewed science papers (Pecl et al., 2017). Nothing is published prior to having been cleared by the Skolt Sámi and the families, clans, and organizations involved (Carson and Peterson, 2016).

The Finnish-Norwegian Border River Commission and the ministerial meetings are also attended by representatives of local businesses, municipalities, and mainstream society. The Skolt Sámi are stakeholders in the sense that they are rights holders and participate in the co-management project with knowledge experts who are accepted as such in the local community. They have 
agreed upon and initiated self-imposed harvest limitations of Atlantic salmon to increase the number of mother fish reaching the spawning areas within these state structures. We can define the participation of the Skolts in this forum as one of many stakeholders and representatives. This structure does not, however, hold any specific mechanisms for the Sámi to participate or take governance steps, as specifically Sámi measures, to govern, manage or influence the Näätämö basin or the Atlantic salmon. For years and decades, the official structure has been in need of reform to decentralize the decisions and priorities away from the state level to answer the burning questions of those engaged at local and basin-wide levels.

It was out of these needs and concerns that the Näätämö River Co-Management Project (Mustonen and Feodoroff, 2013), led and designed by the Skolts, arose in 2011. Six years of implementing the co-management project have revealed some lessons learned, including mistakes, successes, and achievements of the project.

Concerning its policy relevance, the project remains a project. Although ambitious and wide in scale and scope, it has been kept as a project, as the overall situation of Sámi and natural resources questions, including Atlantic salmon issues, have spiraled into an uncontrollable chaos in Finland because of the legal-administrative reforms of 2012-18 (that is, the reforms to the Metsähallitus Act, whereby many parts of the Näätämö basin were transferred from protected areas into a "third" administrative land base that has not been defined to date, but technically allows industrial land use). These reforms have severely weakened the overall rights of the Sámi in Finland (see more in Apgar et al., 2016). Remaining a project has also been seen as a benefit, as a long-term project may be better able to achieve some of the aims than an official process. However, the lack of recognition by the state officials of this type of co-management remains an ongoing challenge. Critically Nadasdy (2003) points to the bureaucratization of traditional knowledge when such issues are codified into the state apparatus. Therefore, the Näätämö Project can also be seen as a successful way to avoid wall-building and large-scale administrative structures.

The links between science and the project have been good (Carson and Peterson, 2016). The discovery of the beetle (Mustonen, 2015), new governance mechanisms, and results have been welcomed in scientific fora and journals. Links between management on the official levels and the project vary, ranging from non-existence to adoption of some of the measures proposed in the co-management steps. Most importantly, these include the system of quotas for both subsistence and tourism harvests. Metsähallitus applied the quota (without consulting with the co-management project) since the co-management plan released by the Sámi came out in 2013, and it is now in place (Mustonen and Feodoroff, 2013).

The successes point to an early relevance of the project after the first seven years. The mechanisms for including TEK and science in a rigorous, community-led study of the basin has proved to be a very meaningful tool for the Sámi to include their voices, knowledge, and observations in a process that has direct links to outcomes. Both the mapping of past damages and changes and the ongoing, mostly weather- or climate-related, observations of salmon and rivers provide mechanisms for the Sámi to improve their self-esteem. A system and a process are in place whereby they, as co-researchers, work to improve the health of the fish and the river.

The most important results of this process are not the observations of change or impacts, but the concrete steps implemented, which include the ecological restoration of habitats in the river Vainosjoki and Kirakkakoski subcatchment areas as well as in Lake Sevettijärvi. Skolt Sámi teams have achieved restoration of grayling and trout habitats that had been destroyed by Metsähallitus in 1968-72, and the harvest of northern pike in the ponds and parts of the main course of the Näätämö is ongoing. The Sámi themselves can implement these interventions, along with the researchers, to increase the survival of smolt and juvenile salmon. These concrete steps are the first of their kind in this context. They will not solve the big issues quickly, but they are real and significant steps at various scales, ranging from actual restoration of habitats to assisting the salmon travelling from the ocean upstream to find cleaner and healthier waters, to renewing and restoring Sámi ways of life.

\section{DISCUSSION}

The different approaches to how traditional knowledge was involved in knowledge production (according to the different models identified by Tengö et al., 2014) play a role in legitimizing the social robustness of the projects (achieving acceptance among not only Indigenous groups, but in the larger society as well). They also influenced policy, which we see as connected to the diversity of actors involved (Table 1). Relations between TEK and science in the different projects varied from the standard "integration and validation" approach (Kolarctic project), to a parallel approach (the joint Norwegian-Sámi working group) to co-production (Näätämö). In terms of legitimacy, as noted earlier in the paper, several criteria should be fulfilled in order to adhere to standards of traditional knowledge in science; here, we have focused on Indigenous participation and acceptance of its application among Indigenous actors. The different models are materialized as differences in who participated as knowledge holders and what knowledge they participated with in each example. In all three examples, salmon fishers, Indigenous Sámi organizations, and local knowledge or TEK were variously involved at different levels in each knowledge production process.

For the Kolarctic project, research on coastal salmon fishers' observations and knowledge was included in the scientific design and resulted in a genetic database of Atlantic salmon stocks from the Kolarctic project. The 
TABLE 1. Comparing knowledge production involving traditional knowledge across examples

\begin{tabular}{llll}
\hline \hline Criteria & Kolarctic project & Joint working group & Näätämö project \\
\hline Context, goal, and method & $\begin{array}{l}\text { Scale sample research project on } \\
\text { genetic distribution of salmon stocks } \\
\text { in fishers' catches to arrive at new } \\
\text { knowledge on mixed-stock harvest in } \\
\text { northern Norway }\end{array}$ & $\begin{array}{l}\text { Working group created by the } \\
\text { Directorate for the Environment } \\
\text { to arrive at new policy on salmon } \\
\text { regulations in northern Norway }\end{array}$ & $\begin{array}{l}\text { Co-management project between } \\
\text { Skolt Sámi and Snowchange to } \\
\text { contribute to restoration of Näätämö } \\
\text { catchment area }\end{array}$
\end{tabular}

Outcomes in terms of salmon sustainability

Stakeholder position (Sámi rights holder, knowledge holder)

Knowledge production model

Diversity of actors involved

Salience (relevance for the needs of policy makers):

Legitimacy

Level of participation of Sámi/local actors

Acceptance of application among Indigenous groups (social robustness)

Credibility

Influence on policy

\begin{abstract}
New tool for identifying the origin of salmon in coastal mixed-stock fisheries; for example, discovery of high proportion of Russian salmon in Varanger coastal fishery
\end{abstract}

Sea-based salmon fishers participating as stakeholders and private rights holders

\section{Integration and validation}

Salmon biologists, salmon fishers, Finnmark County Governor

Directly relevant

Low

Fishers participated in data collection and sampling

Varying, depending on regional outcome and benefits to fishers

\section{High}

Direct implications. Results on genetic patterns in the mixed-stock fishery accepted by policy makers and most fishers
None

Restoration of river, discovery of invasive species, establishment of a working community observation network, self-imposed per family quotas, detection of expansion of pike

Fishers and Sámi organizations as stakeholders in management

Fishers and villages enjoying special Skolt Sámi rights

Parallel approach

Salmon fisher organizations, Sámi Parliament, Directorate for the Environment

Not very relevant

High

Fishers' organizations participated in joint working group with management body and Sámi Parliament

None at all

Low

Negative implications.

Discontinuation of dialogue between

authorities, fishers, and Sámi Parliament
Co-production

Snowchange, Saa'mi Nu'ett cultural organization, fishers, TEK experts, teams of scientists

Partly relevant

High

Specific Sámi participation at all levels from data collection to control of project

High

High

Few implications. High local and international acceptance; the method is beginning to be accepted among regional and national policy makers results of the research were used in the knowledge basis for salmon management, which speaks directly to its policy relevance. However, the legitimacy of the knowledge production process, especially concerning the limited participation (in data collection only) of the coastal salmon fishers, can be questioned. In a Sámi and Arctic context, the inclusion of individual fishers as data collectors and not as knowledge holders and partners in a project such as this might be problematic, as the expectation of what the inclusion of TK means is much more comprehensive than just including fishers as data collectors, as referred to in the Ottawa principles.

In the joint working group, fishers and Sámi organizations were equal participants in the production of the report, and the process included an expert report on TEK, although the initiative was stopped at the political level in Norway. For the Näätämö project, the Skolt Sámi were themselves in the lead of the co-management project, and they appointed their own TEK experts to participate in the scientific team for the project. Thus, in terms of expectations about traditional knowledge relations with science, only the Näätämö project comes out as fulfilling expectations of Indigenous participation at all levels, as Indigenous knowledge holders co-producing knowledge together with scientists.

Putting the Näätämö, Kolarctic and Sámi-Norwegian joint working group into the context of national and Fennoscandian issues of TEK relations with science leads us to grasp a number of facts. The Näätämö co-management process was clearly regarded as legitimate by its participants, but lacking in policy relevance at Finnish national levels. Although its policy relevance as a management approach can be questioned since it remains a project and not an official part of the salmon management system, it still has had a concrete impact on salmon sustainability in the Neiden/Näätämö River catchment area. It is striking, however, in terms of salience, that while the Näätämö project began to have an impact on policy in the region only several years into its operation, the Kolarctic project was directly relevant to national salmon management policies. Part of the reason lies in the fact that, in contrast to other parts of the Sámi space, there are (albeit soft) legal frameworks in place to support Skolt Sámi participation in environmental governance and monitoring 
work. Their status as rights holders gives them a unique position as legitimate knowledge holders from the outset.

This enactment of Indigenous knowledge in the Näätämö project is worth explaining further. Skolts, after the relocation of 1944, acquired special rights within the Skolt Act, guaranteeing their living space as a primary location to be used for "traditional Sámi lifeways" (Mustonen and Feodoroff, 2013) such as herding, hunting, and fishing. Therefore back in 2011 the wishes of the Skolt Sámi to co-develop better and more effective governance models for the Näätämö catchment area were built on the special context of the area and their positions as formal rights and knowledge holders. In 2011-14, a baseline was produced on traditional land uses, biogeographical information about water bodies, and climate change drivers in the river system. In 2015-17, this newly discovered information (in cooperation with scientists) led to the ecological restoration of those spawning areas and habitats that had been altered by the state in the post-war context. These sites can be seen as cultural indicators of resilience. Restoration on these first sites was completed in October 2017. Unfortunately, while this work has motivated the Skolts and produced concrete results, it has not translated, as of yet, into a reform or a serious transformation of those state agencies and officials who form the power levels of river governance (Apgar et al., 2016). Ecological restoration of habitats and mitigation of past damages from the 1950-80 period are difficult issues for these agencies, as they challenge the "pristine wilderness" narrative about the basin and provide a sociohistorical baseline of habitat alterations, including the hydropower development and diversion of the stream flow of the Kallojoki River on the Norwegian side (Feodoroff and Mustonen, 2013). Although Indigenous groups are rarely encouraged to take responsibility for the credibility of TEK, this is what was achieved in the Näätämö project, and it was also discussed in the joint Norwegian-Sámi working group. The Skolt Sámi example thus gives a hint of what could have been achieved through a knowledge co-production process for the sea-based salmon fisheries in Finnmark. For instance, while a priority focus on predation affecting salmon survival was implemented for the Neiden River, as noted by Joks and Law (2016), the role of predators in salmon survival was not considered relevant by salmon scientists at the time. In later research projects, however, the local management organization for the Tana River collaborates with scientists from the Norwegian Institute of Nature Research to investigate the role of predators on salmon (Tanavassdragets Fiskeforvaltning, 2018).

Regarding co-production of knowledge, the abandoned Sámi-Norwegian co-production process and the Näätämö co-management process both used the kind of co-production procedures that Tengö (2014) and Rybråten and Gómez-Baggethun (2016) advise, starting with mutual goal formulation. Although one goal of the Kolarctic project was to include traditional knowledge (cf. Niemelä et al., 2014), the project's main approach was to involve fishers as data providers in the data collection phase of the project. This in itself is not wrong, as many citizen science projects do this with great success for research projects and increased learning among the public groups that are involved. However, compared to the Näätämö project, the Kolarctic project was clearly one in which the method was not to engage in a collaborative process with the salmon fishers, but to hire them on as data collectors and providers of knowledge. Only the Näätämö/Neiden River fishers seemed to have the capacity to engage in a collaborative process with a team of researchers and get to the point where knowledge was co-produced and had an effect on salmon management. Again, this is where we think that the clear delineation of the Skolt Sámi territory comes into play, but also the knowledge production model employed.

Assessing the Näätämö project in terms of legitimacy, the dialogue between Sámi and researchers has been rather successful (Apgar et al., 2016), but dialogue between Sámi and the state has been missing, as is the case in the historical context. The Skolt Sámi Council decided to make a co-management partnership official in 2015, demonstrating the meaningfulness for those sectors where the Sámi and partnering scientists have been able to work together. Governmental agency involvement is emerging. Reflecting, as one of the key science members of the team, we see a need to allow for the space, time, and context of the culturally specific Sámi observations to emerge through their own epistemologies. There is no way to rush this process, even though it may be frustrating compared to faster scientific data results, fish stock surveys, or geomapping. In fact by allowing the Sámi to "take their time," the Näätämö work tries to address the concerns Nadasdy (2003) has raised in the established co-management regimes from North America. It is a way to combat imposition and token co-managerialism, but it does take time, trust, and a place for these observations and knowledge to be included.

For the Norwegian case, however, the fishers participating in the Kolarctic project did not see their participation as meaningful if it did not return tangible benefits in terms of extended allowable fishing periods. Nonetheless, the project results continue to have a real impact on salmon sustainability and on management regulations (decisions on fishing times for the coastal salmon fishery in Norway, e.g., Office of the Finnmark County Governor, 2018), most probably because of the scientific credibility of the resulting genetic database for wild salmon in the Barents region (Ozerov et al., 2017).

For the Norwegian and Finnish governments, their first and foremost obligation is salmon conservation, with little formal impetus to give special priority to Sámi salmon fishers, as illustrated by the political dismissal of the Norwegian-Sámi joint working group. Although the general principles of traditional or experience-based knowledge inclusion are in place, the environmental ministries tend to trade away this rather "unknown and messy field" for what they perceive as organized, legitimate, and credible knowledge produced by authorized salmon scientists. Rather than leading to adaptive management practices 
in the salmon governance system, such as setting up co-management boards with both sea-based and riverine harvest groups for each identified salmon stock, in the current situation the legitimacy for future salmon research projects seem to be low both among Sámi salmon fishers and in the Sámi Parliament. In fact, sea-based salmon fisher organizations are seeking justice through national and international court systems on the grounds that their fishing rights are being violated (UN Human Rights Council, 2016; Sámi Parliament, 2017).

To sum up, we can say that so far, the projects that seem to fulfill Arctic expectations of traditional knowledge co-production with science (projects with high legitimacy) seem to have the least impact on policy, and vice versa (Table 1). Why is it like this, and what are the implications for the social robustness of Arctic traditional knowledge co-production processes?

\section{CONCLUSIONS}

In this article we have reviewed Atlantic salmon governance in Finland and in Norway, and also how international policies of traditional Indigenous knowledge manifest themselves but are diverted once they reach the national and local context. Traditional knowledge seems to matter most in international and Arctic policy guidelines and in political expectations of its integration with science. Our main finding is the large gap between these expectations and their manifestation at the national and local levels in terms of legitimacy (the extent to which Indigenous groups participate in knowledge production and its social robustness) and salience (relevance to the needs of the policy makers of the projects) in the examples we have reviewed. In the trade-off between legitimacy and credibility, we find that international and Arctic policies on traditional knowledge place greater emphasis on legitimacy and credibility plays a minor role, while the reverse is true for nation-state environmental policy. Another important finding is that Sámi groups who are rights holders and represent a clearly defined territory seem to form better working relations in research than groups in cases where there is no recognition of collective Sámi rights. The Näätämö case stands out as one of the few cases in which salmon knowledge co-production has been conducted in a way that holds legitimacy among local resource users and knowledge holders, which we see as tied to the unique legal-social context of the Skolt Sámi in this watershed. This case has also produced tangible results.

We see the gap between Arctic expectations and their lack of implementation as connected to the politicization of research in Indigenous contexts, unrealistically high expectations of the role of TEK, and overly formalistic approaches to what it means to include TEK in research. For instance, the way TEK is materialized as a result of international policies seems to be in the production of traditional knowledge holders as stakeholders (e.g., in the
Ottawa Traditional Knowledge Principles). In a worstcase scenario, if taken seriously, the focus on integrating multiple knowledge systems might send people on a hunt for an appropriate TEK representative instead of involving the whole community with its multiple voices and interests (i.e., Tengö et al., 2014). The attempt to find those who seem to fit the political definitions of traditional knowledge system representatives could silence other, equally valid, voices. The emphasis on TEK gatekeepers could lead to a reproduction of many of the problems that Western academics have been criticized for, and to which a more inclusive and democratic scientific knowledge production system was to provide a solution (cf. Nowotny et al., 2001). This result, however, depends on how scientists and local communities interpret and produce traditional knowledge in relation to science on the ground.

To achieve both social robustness and policy relevance, we argue that one needs to pay attention to both scientific credibility and what is perceived locally as legitimate knowledge production processes. How could this be achieved? Rybråten and Goméz-Baggethun (2016:65), referring in particular to Norwegian salmon management, recommend a "locally based, multidisciplinary research project on LEK and salmon," starting with a joint definition of the target for the process, as advocated also by Tengö et al. (2014) as part of the IPBES' multiple evidence-based approach. The desired result is a knowledge production process in which actors should be clearly defined and be able to agree on common goals, as well as produce new knowledge, as part of the same governance process.

To what extent is the Näätämö case an example of such an approach? The Näätämö approach, while it has missed the progress made on the Arctic levels, has had some advantages in terms of its legitimacy and meaningfulness for its participants. The Skolts have been able to include, from their viewpoint, the endemic concepts (Mustonen, 2015; Mustonen and Mustonen, 2016): governance, land uses, songs, practices, knowledge and its "unbound" characteristics in the project because of the space and "freedom" this approach has provided. We should not dismiss this experience simply because it has not always been compatible with the official or preconceived notions of Sámi knowledge. In fact, the devolution of definition and scalable power of Sámi knowledge to the women and men, the fishermen and cultural leaders involved in the work, has provided new science results, such as the early detection of a scarabaeid beetle (Mustonen, 2015), which is more than a narrowly defined fish-scale sampling could have achieved.

When it comes to translation of Arctic definitions, scales and relevance of traditional knowledge, Indigenous knowledge, the Ottawa principles and Permanent Participant policies have been largely irrelevant for the Näätämö project and the new measures. Some of the Sámi involved in the Näätämö project have used some of the rhetoric at the local level in discussions on Sámi knowledge, but beyond that, the Näätämö project has operated on undefined or endemically defined spaces for 
Sámi Indigenous knowledge (Apgar et al., 2016; Carson and Peterson, 2016). Success has been demonstrated, however, when third parties (e.g., science organizations) have formed direct bilateral partnerships, under the UN, with the Sámi, which has been the case with the Näätämö co-management project.

For the coastal salmon fishery and the Tana River context, which involves Sámi on both the Norwegian and Finnish sides of the river, there seems to be a much shorter distance between international networks and concepts and their application to local situations (i.e., the Ellos Deatnu movement, Holmberg, 2018). The largest difference between the Näätämö and the Norwegian Sámi contexts, in this sense, is perhaps the lack of politicization of the Neiden River salmon governance and the failure to legitimately include Sámi participation in Norwegian salmon governance. With the abrupt end of the joint working group with the Finnmark salmon fisher organizations and the breach of consultations with the local Tana River fisheries management board, the table has been set for political agitation using and appealing to international norms for Indigenous participation in decision making. Traditional knowledge has played a role in these cases, but norms for inclusion of Indigenous and local knowledge have not played as extensive a role in the Sámi discourse as it seems to have done in North American Indigenous discourses on co-management of resources.

As this article has highlighted, part of the reason for this contrast could be that ongoing relations between scientists and local people already exist in terms of collecting data (Kolarctic salmon project) and monitoring salmon habitats (Näätämö), which provide the impetus for healthy salmon co-management in both Norway and Finland. Perhaps the most important realization from this inquiry is that the absence of international TEK and ILK definitions in some local and regional contexts has allowed Indigenous people (e.g., the Skolt Sámi) to carve their own spaces and interpretations for the rather general terms of Indigenous and local knowledge and practice. While this situation has produced scientifically relevant observations of arrival species (Mustonen, 2015) or ecological restoration (Apgar et al., 2016), these undefined spaces and contexts are extremely relevant for the regional discussions on local and Indigenous knowledge. The risks associated in embracing the "unbound" and diverse knowledges of Sámi should thus be reflected against the unity of TEK definitions and their locations inside the national and international contexts in the future.

Building on the evidence from the existing monitoring and co-management processes, we encourage rethinking what a policy-relevant Arctic knowledge co-production process should look like. This might mean giving up on the idea of traditional knowledge as a system of knowledge comparable to science in order to achieve the most salient results, and in the end, socially robust knowledge. In the case of the Näätämö project, we believe that part of the reason for its success is exactly the complementary co-production approach, the status of a Sámi collective as rights holders, and its lack of definition of TEK as a system or body of knowledge, which allowed for the participants' Skolt Sámi knowledge to influence the research. The project has transformed the Skolt Sámi from victims of climate change impacts into agents of transformation who are restoring habitats to increase salmon resilience in less than a decade. Although lacking official recognition, a remarkable path of success emerges if all parties are willing to share, explore, and implement knowledge in new ways for the improvement of nature and people.

\section{ACKNOWLEDGEMENTS}

Camilla Brattland's contribution was made possible as part of the post-doctoral project "Arctic Governance and Indigenous Innovation" at UiT-The Arctic University of Norway and the IndGov project at the Fram Centre, Tromsø. The author is also grateful to comments on earlier paper draft presentations by John Law and other participants at two workshops organized by Kristin Asdal in Kabelvåg and Tromsø (the "Little Tools" project) in March 2017 and April 2018.

Tero Mustonen's contribution was made possible by the SOVIKO Project at the University of Eastern Finland and the Snowchange Cooperative, Finland. A paper draft was also presented at the ICASS IX Conference in Umeå, Sweden, in 2017, where valuable discussions and comments followed. The authors are also grateful for the constructive comments of the anonymous reviewers.

\section{REFERENCES}

Agrawal, A. 1995. Dismantling the divide between Indigenous and scientific knowledge. Development and Change 26(3):413 - 439. https://doi.org/10.1111/j.1467-7660.1995.tb00560.x

AMAP (Arctic Monitoring and Assessment Programme). 2017. Adaptation actions for a changing Arctic: Perspectives from the Barents Area. Oslo, Norway: AMAP.

Apgar, J.M., Mustonen, T., Lovera, S., and Lovera, M. 2016. Moving beyond co-construction of knowledge to enable selfdetermination. IDS (Institute of Development Studies) Bulletin 47(6):55-72.

http://dx.doi.org/10.19088/1968-2016.199

Arctic Council. 2013. Arctic Biodiversity Assessment. Akureyri, Iceland: Conservation of Arctic Flora and Fauna (CAFF). http://www.arcticbiodiversity.is

Arctic Council Indigenous Peoples' Secretariat, 2014. Ottawa traditional knowledge principles. Tromsø, Norway: Indigenous Peoples' Secretariat.

http://www.saamicouncil.net/fileadmin/user_upload/ Documents/Eara_dokumeanttat/Ottawa_TK_Principles.pdf

Berkes, F. 2008. Sacred ecology: Traditional ecological knowledge and resource management, 2nd ed. New York: Routledge. 
2009. Evolution of co-management: Role of knowledge generation, bridging organizations and social learning. Journal of Environmental Management 90(5):1692 - 1702.

https://doi.org/10.1016/j.jenvman.2008.12.001

- 2012. Implementing ecosystem-based management: Evolution or revolution? Fish and Fisheries 13(4):465 - 476. https://doi.org/10.1111/j.1467-2979.2011.00452.x

Carson, M., and Peterson, G., eds. 2016. Arctic Resilience Report, 2016. Stockholm, Sweden: Arctic Council and Environment Institute and Stockholm Resilience Centre. http://www.arctic-council.org/arr

Cash, D., Clark, W.C., Alcock, F., Dickson, N.M., Eckley, N., and Jäger, J. 2002. Salience, credibility, legitimacy and boundaries: Linking research, assessment and decision making. KSG Working Papers Series RWP02-046.

https://doi.org/10.2139/ssrn.372280

Cash, D.W., Clark, W.C., Alcock, F., Dickson, N.M., Eckley, N., Guston, D.H., Jäger, J., and Mitchell, R.B. 2003. Knowledge systems for sustainable development. Proceedings of the National Academy of Sciences 100(14):8086-8091. https://doi.org/10.1073/pnas.1231332100

CBD (Convention on Biological Diversity) Secretariat. 2018. Akwé: Kon guidelines.

https://www.cbd.int/traditional/guidelines.shtml

Díaz, S., Demissew, S., Carabias, J., Joly, C., Lonsdale, M., Ash, N., Larigauderie, A., et al. 2015. The IPBES conceptual framework - connecting nature and people. Current Opinion in Environmental Sustainability 14:1-16.

https://doi.org/10.1016/j.cosust.2014.11.002

ELY (Elinkeino-, liikenne- ja ympäristökeskus). 2018. Vapaa-ajan kalastus Suomessa [Sports fishery in Finland]. http://www.ely-keskus.fi/web/ely/vapaa-ajan-kalastus

Eythórsson, E., and Brattland, C. 2012. New challenges to research on local ecological knowledge: Cross-disciplinarity and partnership. In: Carothers, C., Criddle, K.R., Chambers, C.P., Cullenberg, P.J., Fall, J.A., Himes-Cornell, A.H., Johnsen, J.P., Kimball, N.S., Menzies, C.R., and Springer, E.S., eds. 2012. Fishing people of the North: Cultures, economies, and management responding to change. Fairbanks: Alaska Sea Grant, University of Alaska Fairbanks. 131-152. https://doi.org/10.4027/fpncemrc.2012.11

Fenge, T., and Funston, B.W. 2009. Arctic governance: Traditional knowledge of Arctic Indigenous peoples from an international policy perspective. Paper presented for the Arctic Governance Project. http://www.arcticgovernance.org/getfile.php/1092554.1529. rpcpqrspuy/Traditional + Knowledge + Paper + Fenge + Funston + Dec+2009.pdf

Gross, M. 2006. Beyond expertise: Ecological science and the making of socially robust restoration strategies. Journal for Nature Conservation 14(3-4):172-179. https://doi.org/10.1016/j.jnc.2006.05.004
Guttorm, G. 2011. Árbediehtu (Sámi traditional knowledge)as a concept and in practice. In: Porsanger, J., and Guttorm, G., eds. Working with traditional knowledge: Communities, institutions, information systems, law and ethics. Writings from the Arbediehtu Pilot Project on Documentation and Protection of Sámi Traditional Knowledge. Dieđut 1. Guovdageidnu, Norway: Sámi Allaskuvla, Sámi University College.

Harris, D.C. 2009. Landing Native fisheries: Indian reserves and fishing rights in British Columbia, 1849-1925. Vancouver, British Columbia: UBC Press.

Holmberg, A. 2018. Bivdit Luosa - To ask for salmon. Saami traditional knowledge on salmon and the river Deatnu: In research and decision-making. Master's thesis in Indigenous Studies. UiT - The Arctic University of Norway, Tromsø.

Horn, K.-S., and Abelsen, T. 2016. Angriper laksefisket i sjøen: De slipper dugnaden og driver ikke lønnsomt [Attacks on the seabased salmon fishery: They do not contribute and the fishery is not economically viable]. NRK Finnmark, November 25.

https://www.nrk.no/finnmark/angriper-laksefisket-i-sjoen_-_de-slipper-dugnaden-og-driver-ikke-lonnsomt-1.13245219

Johnson, N., Alessa, L., Behe, C., Danielsen, F., Gearheard, S., Gofman-Wallingford, V., Kliskey, A., et al. 2015. The contributions of community-based monitoring and traditional knowledge to Arctic observing networks: Reflections on the state of the field. Arctic 68(Suppl. 1):28-40.

https://doi.org/10.14430/arctic4447

Joks, S. 2016. "Laksen trenger ro.” Tilnærming til tradisjonelle kunnskaper gjennom praksiser, begreper og fortellinger fra Sirbmá-området ["Salmon needs rest." Approaches to traditional knowledges through practices, concepts and narratives from the Sirbmá area]. PhD thesis, UiT- The Arctic University of Norway, Tromsø.

Joks, S., and Law, J. 2016. Sámi salmon, state salmon: LEK, technoscience and care.

http://www.heterogeneities.net/publications/JoksLaw 2016SamiSalmonScienceSalmon.pdf

Lam, M.E., and Borch, T. 2011. Cultural valuing of fishery resources by the Norwegian Saami. In: Westra, L., Bosselmann, K., and Soskolne, C., eds. Globalisation and ecological integrity in science and international law. Newcastle upon Tyne: Cambridge Scholars Publishing. 361-376.

https://doi.org/10.5848/CSP.2833.00020

Law, J. 2004. Matter-ing: Or how might STS contribute? Lancaster, United Kingdom: Centre for Science Studies, Lancaster University.

http://www.lancaster.ac.uk/fass/resources/sociology-onlinepapers/papers/law-matter-ing.pdf

Metsähallitus. 2013. Akwé: Kon ohjeiden soveltaminen Hammastunturin erämaa-alueenhoito-jakäyttösuunnitelmaan. [Application of Akwé: Kon guidelines in the management and land use plan for the Hammastunturi Wilderness Area. Final report]. Metsähallitus, Natural Heritage Services. Available at: http://julkaisut.metsa.fi/assets/pdf/lp/Muut/Akwe Konraportti2013.pdf 
Ministry of Climate and Environment. 2006-07. Om vern av villaksen og ferdigstilling av nasjonale laksevassdrag og laksefjorder [Proposition to the Storting: On conservation of wild salmon, national salmon rivers and salmon fjords]. Oslo: Klima- og miljødepartementet.

Mustonen, T. 2013. Power discourses of fish death: Case of Linnunsuo peat production. Ambio 43(2):234-243. https://doi.org/10.1007/s13280-013-0425-3

- 2015. Communal visual histories to detect environmental change in northern areas: Examples of emerging North American and Eurasian Practices. Ambio 44(8):766-777. https://doi.org/10.1007/s13280-015-0671-7

Mustonen, T., and Feodoroff, P. 2013. Ponoi and Näätämö River Collaborative Management Plan. Kontiolahti: Snowchange Cooperative.

Mustonen, T., and Mustonen, K. 2011. Eastern Sámi atlas. Kontiolahti: Snowchange Cooperative.

—. 2016. Life in the cyclic world: A compendium of traditional knowledge from the Eurasian North. Kontiolahti: Snowchange Cooperative.

ht tp://www.snow change.org/pages/wp-content/ uploads/2016/05/life-in-the-cyclic-world-final-250516.pdf

Nadasdy, P. 1999. The politics of TEK: Power and the "integration" of knowledge. Arctic Anthropology 36(1/2):1-18.

2003. Hunters and bureaucrats: Power, knowledge and Aboriginal-State relations in the Southwest Yukon. Vancouver, British Columbia: UBC Press.

2006. The case of the missing sheep: Time, space, and the politics of "trust" in co-management practice. In: Menzies, C., ed. Traditional ecological knowledge and natural resource management. Lincoln: University of Nebraska Press. 127-151.

NASCO (North Atlantic Salmon Conservation Organization). 2009. NASCO guidelines for the management of salmon fisheries.

http://www.nasco.int/pdf/far_fisheries/Fisheries\%20 Guidelines\%20Brochure.pdf

2014. Report of the Thirty-First Annual Meeting (2014),

Saint-Malo, France.

http://www.nasco.int/reports_annual.html

.2015. Report of the Thirty-Second Annual Meeting (2015).

Happy Valley-Goose Bay, Newfoundland and Labrador.

http://www.nasco.int/reports_annual.html

Niemelä, E., Erkinaro, J., Kylmäaho, M., Julkunen, M., Moen, K. 2001. Näätämöjoen lohen poikastiheys ja kasvu [Growth and density of parrs, frys and smolts of Atlantic salmon in the Näätämö River]. Helsinki: Riistan- ja kalantutkimus. Kalatutkimuksia: 176.

Niemelä, E., Hassinen, E., Haantie, J., Kuusela, J., Aro, P., Metsola, S., and Kalske, T. 2014. Escaped salmon in salmon fishers' catches. Kolarctic report. Kolarctic ENPI CBC project (KO197) - Report V.

https://prosjekt.fylkesmannen.no/Kolarcticsalmon/ Documents/Reports/Scientific-reports/

Nowotny, H., Scott, P., and Gibbons, M. 2001. Re-thinking science: Knowledge and the public in an age of uncertainty. Cambridge: Polity.
Office of the Finnmark County Governor. 2013. Kolarctic salmon $2011-2013$. https://prosjekt.fylkesmannen.no/Kolarcticsalmon/

-2018. Fisketider for sjølaksefiske 2018 [Fishing times for the coastal salmon fishery 2018]. Fylkesmannen i Finnmark.

https://www.fylkesmannen.no/nn/Finnmark/Miljo-og-klima/ Fiskeforvaltning/Fisketider-for-sjolaksefiske-2018/

Ozerov, M., Vähä, J.-P., Wennevik, V., Niemelä, E., Svenning, M.A., Prusov, S., Diaz Fernandez, R., et al. 2017. Comprehensive microsatellite baseline for genetic stock identification of Atlantic salmon (Salmo salar L.) in northernmost Europe. ICES Journal of Marine Science 74(8):2159-2169.

https://doi.org/10.1093/icesjms/fsx041

Pecl, G.T., Araújo, M.B., Bell, J.D., Blanchard, J., Bonebrake, T.C., Chen, I-C., Clark, T.D., et al. 2017. Biodiversity redistribution under climate change: Impacts on ecosystems and human wellbeing. Science 355(6332), eaai9214.

https://doi.org/10.1126/science.aai9214

Pedersen, S. 2010. '5. Sjølaksefisket i Finnmark til midten av 1800-tallet' i Sjølaksefisket i Finnmark i et historisk perspektiv. Utredning for Finnmarkskommisjonen [The sea-based salmon fishery in Finnmark until the middle of the 1800s. Report for the Finnmark Commission]. Kautokeino: Sámi allaskuvla/ SEG.

. 2011. Tradisjonell kunnskap og laks. Noen momenter. Rapport til arbeidsutvalg knyttet til reguleringer i fisket etter anadrome laksefisk [Traditional knowledge and salmon. Some issues. Report to the working group for regulation of anadromous salmon fishery]. In Directorate for Nature Management and Sámi Parliament. 2011. Direktoratet for Naturforvaltning og Sametinget: Regulering av fisket etter anadrome laksefisk i Finnmark og Nord-Troms for 2012. Rapport fra arbeidsutvalg [Regulation of anadromous salmonids fisheries in Finnmark and Northern Troms for 2012. Report from working group]. Oslo and Karasjok: Sametinget.

http://www.miljodirektoratet.no/old/dirnat/multimedia/52580/ Steinar-Pedersen-Tradisjonell-kunnskap-og-laks.-Noenmomenter-sakkyndig-rapport-ENDELIG.pdf

Roué, M., and Nakashima, D. 2002. Knowledge and foresight: The predictive capacity of traditional knowledge applied to environmental assessment. International Social Science Journa 54(173):337-347. https://doi.org/10.1111/1468-2451.00386

Rybråten, S., and Gómez-Baggethun, E. 2016. Lokal og tradisjonell økologisk kunnskap i forskning og forvaltning av laks. En forstudie [Local and traditional ecological knowledge in salmon research and management. A preliminary study]. Trondheim: NINA Rapport 1290. 80 p.

Sámi Parliament. 2017. Sjølaksefiske i Sámiske områder. Plenumsvedtak juni 2017 [Sea-based salmon fishery in Sámi areas. Plenary decision June 2017]. Karasjok: Sametinget.

Schreiber, D., and Brattland, C., eds. 2012. Salmon cultures: Indigenous peoples and the aquaculture industry. Rachel Carson Centre Perspectives No. 4. Munich: Rachel Carson Center. 
Svenning. M.-A., Falkegård, M., Fauchald, P., Yoccoz, N., Niemelä, E., Vähä, J.-P., Ozerov, M., Wennevik, V., and Prusov, S. 2014. Region- and stock-specific catch and migration models of Barents Sea salmon. Kolarctic ENPI CBC-Kolarctic Salmon Project.

https://prosjekt.fylkesmannen.no/Documents/Kolarctic\%20 salmon/Dokument/Scientific $\% 20$ reports/Kolarctic $\% 20$ salmon $\% 20$ exploitation $\% 20$ and $\% 20$ migration $\% 20$ report $\% 20$ Final\%20version.pdf

Tengö, M., Brondizio, E.S., Elmqvist, T., Malmer, P., and Spierenburg, M. 2014. Connecting diverse knowledge systems for enhanced ecosystem governance: The multiple evidence base approach. Ambio 43(5):579-591.

https://link.springer.com/article/10.1007\%2Fs13280-014-0501 $-3$

Tunón, H., ed. 2018. Biodiversity and ecosystem services in Nordic coastal ecosystems: An IPBES-like assessment. Volume 2: The geographical case studies. TemaNord 2018:532. Copenhagen: Nordic Council of Ministers.

http://norden.diva-portal.org/smash/get/diva2:1219772/ FULLTEXT01.pdf
UN Human Rights Council. 2016. Report of the Special Rapporteur on the rights of Indigenous peoples on the human rights situation of the Sami people in the Sápmi region of Norway, Sweden and Finland, 9 August, A/HRC/33/42/Add. 3. http://www.refworld.org/docid/57cd77714.html

Ween, G.B. 2012a. Enacting human and non-human Indigenous: Salmon, Sámi and Norwegian natural resource management. In: Ellefsen, R., Sollund, R., and Larsen, G., eds. Eco-global crimes: Contemporary problems and future challenges. London: Ashgate. 295-313.

- 2012b. Resisting the imminent death of wild salmon: Local knowledge of Tana fishermen in Arctic Norway. In: Carothers, C., Criddle, K.R., Chambers, C.P., Cullenberg, P.J., Fall, J.A., Himes-Cornell, A.H., Johnsen, J.P., Kimball, N.S., Menzies, C.R., and Springer, E.S., eds. 2012. Fishing people of the North: Cultures, economies, and management responding to change. Fairbanks: Alaska Sea Grant, University of Alaska Fairbanks. $153-171$.

https://doi.org/10.4027/fpncemrc.2012.12

Yle. 2017. Sámi activists occupy island in protest of Tenojoki fishing rules. Yle Uutiset, July 13.

https://yle.fi/uutiset/osasto/news/sami_activists_occupy_ island_in_protest_at_tenojoki_fishing_rules/9717663 